Alexander Bown*

\title{
Epicurus on Bivalence and the Excluded Middle
}

DOI 10.1515/agph-2016-0012

\begin{abstract}
In several of his philosophical works, Cicero gives reports of the Epicurean views on bivalence and the excluded middle that are not always consistent. I attempt to establish a coherent account that fits the texts as well as possible and can reasonably be attributed to the Epicureans. I argue that they distinguish between a semantic and a syntactic version of the law of the excluded middle, and that whilst they reject bivalence and the semantic law for fear of certain fatalistic consequences, they endorse the syntactic law. Subsequently, I show that certain principles that they seem to endorse in the context of Cicero's discussion of Chrysippus' argument for fate, when modified by the addition of the atomic swerve, suggest that the Epicureans have in mind something like a supervaluationist model of truth at times, which has the desired results with respect to the three logical principles.
\end{abstract}

\section{Introduction}

No account of Epicurus' views on bivalence and the excluded middle is given in his own extant works. In fact, more or less the only reports to be found are due to Cicero, in De Fato, De Natura Deorum and Lucullus. ${ }^{1}$ Cicero presents these views, together with the famous doctrine of the atomic swerve, as held in response to certain arguments involving necessity and fate whose consequences the Epicureans are unwilling to accept. His accounts are problematic, however: those of Lucullus and De Natura Deorum are so concise that they are hard to make sense of in isolation; and although the treatment in De Fato is more extensive, it too may not be wholly reliable. For Cicero's purpose in the latter is not primarily to report the Epicurean views in themselves, but rather to present them as one possible reaction to an argument for fate that he ascribes to Chrysippus. Epicurus

1 A brief reference is also found in Plutarch (De Pyth. Orac., 398F-399A).

*Corresponding author: Alexander Bown, Département de philosophie, Université de Genève, 2 rue de Candolle, 1211 Genève; alexandre.bown@unige.ch 
himself clearly did have views about fate - indeed, he wrote a treatise called "On Fate"2 - but they can hardly have been a reaction to any argument belonging to Chrysippus, for basic chronological reasons. ${ }^{3}$ One should be wary, therefore, of how Cicero might have distorted the account in using it for his own ends.

There are, at least, a few basic details of Epicurus' position that are clear from his surviving works. First, he rejects the view that everything that happens is antecedently necessary, a view that I shall call "fatalism". (Despite the etymological connection between the terms I use, therefore, fatalism need not directly involve fate: it is simply the view that for anything that is the case at any time $t$, it is necessary at every time earlier than $t$ that it should be the case at $t$. $)^{4}$ Arguments against fatalism are found in the Vatican Sayings and On Nature, ${ }^{5}$ while in the Letter to Menoeceus (133f.) Epicurus divides things which happen into three groups: those that do so necessarily, those that do so by chance, and those that depend on us. ${ }^{6}$ It seems likely, therefore, that he would reject fatalism as a view which renders at least the second class empty. ${ }^{7}$ Secondly, the latter passage also contains a mention of fate:

Because it would be better to adhere to the legends about the gods than to be enslaved by the fate of the physicists: for the former traces out a hope of entreating the gods by means of worship, whereas the latter has a necessity of which there is no entreaty. ${ }^{8}$

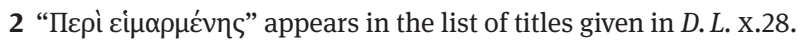

3 Chrysippus was born in 279 BC; Epicurus died in 270 BC. Later Epicureans clearly did respond to Chrysippus' arguments for fate, however: one such example is Diogenianus, an Epicurean philosopher of the second century Bс. See Isnardi Parente 1990, 2426-31.

4 I borrow the useful schema "At $\tau$, it is necessary that $\alpha$ at $\tau$ '” from Crivelli 2004, 199.

5 The argument found in book XXV of On Nature ([34.26-30] Arrighetti; Laursen 1997, 32-41) bears similarities to that given as no. 40 of the Vatican Sayings: "He who says that everything happens according to necessity cannot criticize someone who says that not everything happens according to necessity: for he claims that the latter event itself happens according to necessity." See Sedley 1983, 16-40, for more details.

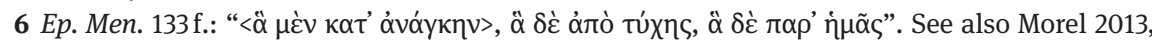
$172-4$.

7 Most discussions of Epicurus' views on these matters have focused on the defence of the third class instead: one question discussed at length is that of whether or not Epicurus had something like a notion of free will. I will not discuss this controversial topic at all, but concentrate only on the second class, which is all that is needed to motivate the Epicurean positions on bivalence and the excluded middle.

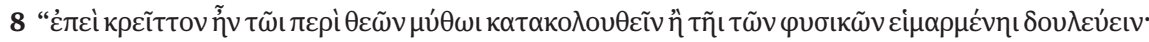

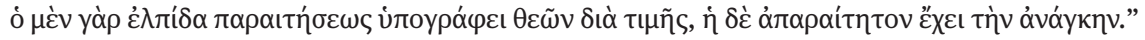


Leaving aside the question of precisely who "the physicists" should be taken to be, ${ }^{9}$ the passage seems good evidence that Epicurus would reject at least some version of fate because he thinks that it brings necessity with it. At first glance, this looks like a hint that he might think that fate entails fatalism, and so might reject the former in order to be able to deny the latter.

I aim to use these basic aspects of their position - namely that they deny fatalism and that they reject some version of fate in order to avoid some of its consequences involving necessity - as a guide with which to extract from Cicero's accounts a position on which truth values statements can have at which times that can reasonably be attributed to the Epicureans. Furthermore, I aim to show that this position is coherent, fairly subtle, and certainly not as implausible as Cicero thinks. I will first present an argument for fatalism and argue that the Epicureans respond to it by denying that bivalence applies universally but nonetheless affirming a version of the law of the excluded middle. Subsequently, I will show that certain principles concerning the truth of statements about the future which Cicero reports the Epicureans to endorse in response to the Chrysippean argument for fate, when taken together with the Epicurean theory of the atomic swerve, naturally yield an account of truth at times that has the correct results for bivalence and the excluded middle.

One final introductory remark remains to be made. Epicurus rejected abstract items like propositions; rather, he seems to have regarded (token) utterances as the bearers of truth values. ${ }^{10}$ Hence, I will report the Epicurean views by speaking in terms of utterances rather than propositions - but the arguments I present do not depend on this. Furthermore, it should be noted that Epicurus seems (like most ancient philosophers) to be using a tensed notion of truth: an utterance is never true tout court, but rather true at some time or other; and one and the same (token) utterance may be true at one time and become false at another. For example, an utterance of "Socrates is seated" that is made at some time $t$ may be true at the time it is made - because Socrates is indeed seated at $t$ - but become false half an hour later, when he stands up. The idea that a token utterance can have different truth values at different times might seem surprising, but it should be clear on reflection that it is coherent. ${ }^{11}$

9 Plausible candidates include Leucippus, Democritus, and later philosophers influenced by their views; see Sedley 1983, 31-33.

10 See Sextus Empiricus, M. VIII.13, and Plutarch, Adv. Colot. 1119 F.

11 See Crivelli 2004, 183-6, for Aristotle's commitment to the view, and Percival 1994, 198-205, for a modern defence. 


\section{Two Arguments Involving Fate and Necessity}

Cicero begins his main discussion of the Stoic theory of fate in chapter $\mathrm{x}$ of $\mathrm{De}$ Fato. The view that there is fate is to be understood as the view that everything that happens does so according to an eternal chain of efficient causation, a neverending sequence of cause and effect that determines how everything turns out. ${ }^{12}$ Having presented an argument from bivalence to fate that he attributes to Chrysippus (at Fat. x.20 f.), Cicero considers the Epicurean reaction.

T1 (Fat. x.21) ${ }^{13}$ : itaque contendit omnis nervos Chrysippus, ut persuadeat omne $\alpha \dot{\xi}(\omega \mu \alpha$ aut verum esse aut falsum. ut enim Epicurus veretur, ne, si hoc concesserit, concedendum sit fato fieri, quaecumque fiant - si enim alterum utrum ex aeternitate verum sit, esse id etiam certum et, si certum, etiam necessarium; ita et necessitatem et fatum confirmari putat - sic Chrysippus metuit, ne, si non obtinuerit omne, quod enuntietur, aut verum esse aut falsum, non teneat omnia fato fieri et ex causis aeternis rerum futurarum.

And so Chrysippus strains every sinew in order to persuade us that every $\alpha \dot{\xi} \xi \omega \mu \alpha$ [i.e. proposition] is either true or false. For just as Epicurus fears that, if he granted this, he would have to grant that everything comes about by fate, whatever comes about - for if one or the other [sc. of a pair of contradictories] is true from eternity, it is also fixed ${ }^{14}$ and, if fixed, also necessary; thus he thinks that both necessity and fate are the result - so Chrysippus was afraid that, if it did not hold that everything that is asserted is either true or false, it would not hold that everything comes about by fate and from the eternal causes of future things.

Immediately after this passage, the other component of the Epicurean defence is introduced: Epicurus does not just deny bivalence (the view that every proposition at every time is either true or false), ${ }^{15}$ but also claims that there are atomic

12 See Div. I 125, “[...] fate [...] i.e. the sequence and series of causes, since it is cause linked to cause that from itself brings about fact. It is everlasting truth, flowing from all eternity"; see also Servius ad Vergilii Aeneida 3.376, “[...] the definition of fate according to Tullius, who says: 'Fate is a reciprocal connection between things that maintains itself throughout eternity, which varies according to an order and law of its own, but in such a way as for its variation itself to have eternity."”. The latter is generally thought to be a quotation of De Fato.

13 The text is that of Sharples 1991; the translations are my own.

14 The translation of "certus" as "certain" should be rejected as having unwanted epistemic implications. More plausible candidates provided by the Oxford Latin Dictionary include "fixed, settled, definite" (no. 1), "certain to happen or be realized, inevitable, sure” (no. 6), and perhaps "unambiguous, unmistakable, palpable, manifest" (no.9). I use "fixed" as a translation which has at least some of the ambiguities of the Latin word. In so doing, I follow Barnes 2007 but go against Sharples 1991, Bobzien 1998 and O’Keefe 2005.

15 Strictly speaking, Epicurus would express bivalence in terms of utterances rather than propositions, given that he, unlike Chrysippus, denies that there are propositions. 
swerves, i.e. that any atom may causelessly change direction at any time to a minimal and imperceptible degree.

At first sight, it looks in T1 as if there is a straightforward contrast to be drawn between the positions of Epicurus and Chrysippus: it seems that they agree that one must accept either both bivalence and fate or neither, but whereas Epicurus rejects bivalence in order to avoid being compelled to accept fate, Chrysippus accepts bivalence in order to be able to endorse fate. Their positions seem to be exactly opposite. ${ }^{16}$

However, a closer look at the Epicurean side of the picture shows that the contrast between the two positions is not so neat. Its first half - namely "Epicurus fears that, if he granted [bivalence], he would have to grant that everything comes about by fate, whatever comes about" - unproblematically provides the desired contrast with Chrysippus' position. What follows, however, is curious: there is a brief sketch of an argument which involves a progression from being true to being fixed to being necessary (and seems, therefore, not directly to involve fate), then a second statement of the conclusion which worries Epicurus. But this second statement - "thus he thinks that both necessity and fate are the result" is importantly different from the first. Originally, Epicurus was concerned that fate would be the consequence of accepting bivalence; in this new version, he is worried that both fate and necessity would be the result. But in the conclusion which worries Chrysippus at the end of T1, only fate is mentioned. ${ }^{17}$ Indeed, there is good reason necessity is not mentioned in his conclusion. Here, Cicero seems to be using "necessity", as he often does in De Fato, as the name either of fatalism or of the stronger view that for anything that is the case at any time $t$, it is necessary at all times that it should be the case at $t$. But Chrysippus is elsewhere reported as endorsing fate and rejecting necessity ${ }^{18}$; he would therefore have to deny that necessity follows from bivalence. So despite the apparently clear contrast Cicero draws between them, the positions of Epicurus and Chrysippus are not exactly opposite: in particular, they disagree as to what one would have to accept if one accepted bivalence.

16 Cf. Sharples 2007, 58-60.

17 The second conjunct of Chrysippus' conclusion is merely an elaboration of the first: for everything to come about by fate just is for everything to come about "from the eternal causes of future things". Cicero always uses "fate" in this way in these passages (cf. Sedley 2005, 252f.).

18 Cf. Fat. XviII.41: "Chrysippus, however, since he both rejects necessity and wants nothing to come about without antecedent causes [...]”. See Bobzien 1998, 86, for a discussion of Chrysippus' attempts to argue that necessity does not follow from fate. Furthermore, see Bobzien 1993 for a discussion of Chrysippean modality. 
Why, one might wonder, does Cicero mention this view that either is or entails fatalism at all - why does he not confine himself to discussing (Epicurus' views on) fate? After all, at this point in De Fato, he is concerned only with fate; the question of whether or not everything that happens is antecedently necessary is not obviously relevant. The overview I gave of the hints about fatalism and fate found in Epicurus' own works suggests a likely answer. Recall that Epicurus seems to want above all to argue against fatalism, which he finds objectionable in its own right; although he rejects fate too, he does so perhaps because of consequences it has involving necessity. Furthermore, of course, Epicurus cannot have explicitly responded to the Chrysippean argument under discussion. Hence, Cicero's introduction of necessity into the description of the Epicurean position in $\mathrm{T} 1$ could reasonably be taken as an admission that it would be misleading to claim that Epicurus denies bivalence because he wants to reject fate - in fact, the real reason Epicurus denies bivalence is in order to avoid fatalism.

But why should Epicurus think that fatalism follows from bivalence? The argument-sketch that comes between the two versions of the conclusion that worries him provides a hint (I repeat the relevant part of T1):

T1 (Fat. x.21): [...] if one or the other [sc. of a pair of contradictories] is true from eternity, it is also fixed and, if fixed, also necessary [...]

At first glance, it looks like this argument-sketch could reasonably be taken to derive fatalism, or something close to it: it looks like the argument is designed to show that at all times, one of every pair of contradictory utterances is necessary. This would entail that at all times, one of every pair of contradictory future-tensed utterances is necessary - and, indeed, the use of "true from eternity" suggests that future-tensed utterances are particularly in question, as the expression is naturally glossed as something like "true from eternity before the event of which the utterance speaks takes place”. This is not far from fatalism, the view that for anything that happens at any time $t$, it is necessary at every time earlier than $t$ that it should happen at $t$.

However, the sketch is severely lacking in detail. I shall address the following two problems in the next two sections. First, what licenses the two-step progression from something being true to it being fixed and from it being fixed to it being necessary? And second, how is the principle about the truth of pairs of contradictories that begins the argument related to bivalence? For the argument is supposed to derive fatalism from bivalence - but this principle is not bivalence. 


\section{An Argument from Truth to Necessity}

What could underlie the two-step progression from truth to necessity in the argument-sketch of T1? As previously remarked, T1 comes shortly after the beginning of the main discussion of the theory of fate. The discussion of the Epicurean position, however, begins in the preceding chapter, in which Chrysippus is not mentioned. I give almost all this chapter as T2 (Fat. IX.17-20), which I divide into three and discuss section by section. In part (a) is found an argument that, I suggest, is a good candidate for the argument from truth to necessity sketched in T1.

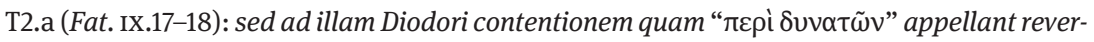
tamur, in qua quid valeat id quod fieri possit anquiritur. placet igitur Diodoro id solum fieri posse quod aut verum sit aut verum futurum sit.

qui locus attingit hanc quaestionem, nihil fieri, quod non necesse fuerit, et, quicquid fieri possit, id aut esse iam aut futurum esse, nec magis commutari ex veris in falsa posse ea, quae futura, quam ea, quae facta sunt; sed in factis inmutabilitatem apparere, in futuris quibusdam, quia non apparet, ne inesse quidem videri, ut in eo, qui mortifero morbo urgeatur, verum sit "hic morietur hoc morbo", at hoc idem si vere dicatur in eo, in quo vis morbi tanta non appareat, nihilo minus futurum sit.

ita fit, ut commutatio ex vero in falsum ne in futuro quidem ulla fieri possit. nam "morietur Scipio" talem vim habet, ut, quamquam de futuro dicitur, tamen ut id non possit convertere in falsum; de homine enim dicitur, cui necesse est mori. sic si diceretur: "morietur noctu in cubiculo suo vi oppressus Scipio", vere diceretur; id enim fore diceretur, quod esset futurum; futurum autem fuisse ex eo, quia factum est, intellegi debet. nec magis erat verum "morietur Scipio" quam "morietur illo modo", nec magis necesse mori Scipioni quam illo modo mori, nec magis inmutabile ex vero in falsum "necatus est Scipio" quam "necabitur Scipio".

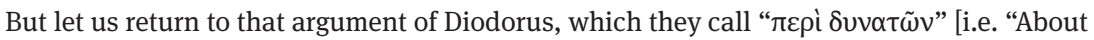
Possibles"], in which he inquires into the force of that which is possible. Well, Diodorus thinks that the only thing that can possibly happen is whatever either is true or will be true. This topic is connected to the argument that nothing comes about without having been necessary, and that whatever can possibly come about is either now the case or will be so, nor can things which will come about be changed from truths to falsehoods any more than things which have happened. But whereas the immutability is evident in the case of that which has happened, in certain things which will happen, because the immutability is not evident it does not seem even to be in them, so that the statement "This man will die from this illness" is true in the case of someone who is being pressed by a deadly disease, but if the same thing is said truly in the case of someone in whom it is not evident that there is so powerful a disease, it will no less come about.

It is thus the case that no change from truth to falsehood can come about, not even in the case of the future. For "Scipio will die" has force of such a kind that, although it is said about the future, still it cannot be changed into a falsehood: for it is said of a man, for whom death is something necessary. Accordingly, if one were to say "Scipio will die at night in his bedroom, overcome by force", one would speak truly, for one would be claiming that that which was going to happen would happen; and indeed, it is a necessary inference from something having happened that it was going to happen. Nor was "Scipio will die" more 
true than "He will die in that way", nor was it more necessary that Scipio should die than that he should die in that way, nor is "Scipio has been killed" any more immutable from truth to falsehood than "Scipio will be killed".

At the beginning of T2.a, Cicero announces that he will return to an old topic, namely Diodorus' definition of the possible. Indeed, he had briefly touched on it some chapters earlier, at viI.13, before discussing Chrysippus' attempts to resist fatalism. ${ }^{19}$ But having reintroduced Diodorus' definition here - "the only thing that can possibly happen is whatever either is true or will be true" - he seems in the second paragraph immediately to change the subject again, turning to a new argument that is somehow 'connected' to this definition. What seems to be the conclusion of this argument is presented as the conjunction of three theses:

(i) Nothing comes about without having being necessary.

(ii) Whatever can possibly come about is either now the case or will be so.

(iii) Things that will come about cannot be changed from truths to falsehoods any more than things which have happened.

It looks like this is primarily an argument for fatalism. For thesis (i) is a straightforward statement of fatalism and, as I shall soon argue, the outline of an argument for it can be found in the passage. Thesis (ii), however, is another occurrence of Diodorus' definition of the possible, differing from the version found in the first paragraph only in that it speaks of things coming about rather than being true. Its presence here is curious, as no arguments are found in the passage for such a definition; indeed, this notion of possibility seems to play no role in what follows. ${ }^{20}$ At any rate, the argument certainly cannot presuppose Diodorus' account of modality when with thesis (ii) Cicero presents it as in part an argument for that account. To the contrary, it turns out that the argument depends only on certain apparently anodyne principles about truth and necessity, which would be acceptable on many accounts of modality.

19 See Weidemann 2007 for a detailed discussion of these sections.

20 Why does Cicero include thesis (ii) if no explicit arguments are given for it? Perhaps because it could plausibly be taken to be a consequence of fatalism. For, given fatalism, it seems likely that for any time $t$ and not earlier time $t^{\prime}$, whatever is the case at $t^{\prime}$ is such that it is necessary at $t$ that it should be the case at $t^{\prime}$, and whatever fails to be the case at $t^{\prime}$ is such that it is necessary at $t$ that it should fail to be the case at $t^{\prime}$. But then there is little space left for the merely possible, and thesis (ii) is correct at least as a characterisation of present and future events: if for some time $t$ something fails to be the case at any time not earlier than $t$, then it is necessary at $t$ that it should fail to be the case at all such times, and hence can hardly be possible at $t$ that it should be the case at some such time. So, as thesis (ii) claims, the only possible present and future events are those that are or will be the case. 
It is perhaps for this reason that Cicero introduces thesis (iii), which should be taken as a deliberate rephrasing of thesis (i). For thesis (iii) differs from thesis (i) only in speaking of immutability from truth to falsehood rather than of necessity and in making it clear that the immutability in question is that which is uncontroversially enjoyed by the past. ${ }^{21}$ It turns out in what follows that one of the two principles on which this argument depends is that the past is immutable; the aim of the argument is to derive the result that what will happen is immutable in just the same way as what has happened. The notion of necessity at play, then, seems to be a low-key notion of necessity as immutability or ineluctability. Indeed, as the passage continues, Cicero uses "necessity" and "immutability" interchangeably.

Before examining the argument in detail, I make a terminological remark. In what follows, it will be useful not just to talk of what is the case at some time, but to have a term that allows one to refer generally to what is the case at some time or times. I shall use "state of affairs" for this purpose. However, it is unclear whether Epicurus would recognise anything like states of affairs in a strong sense as genuine entities, so my use of the term should be understood as non-committal. Take the state of affairs of Scipio being dead; call this " $s$ ". The claim that $s$ obtains in 2014 should be taken as saying no more and no less than the claim that Scipio is dead in 2014; the claim that $s$ did not obtain in 133 BC should be taken as saying no more and no less than the claim that Scipio was not dead in 133 BC. All my talk of states of affairs of individuals having properties obtaining or not obtaining at certain times should be reducible just to talk of those individuals having or failing to have those properties at those times.

With this terminology established, the principles that underlie the argument in T2.a can be expressed as follows:

1) For any state of affairs $s$ and any time $t$, an utterance to the effect that $s$ will obtain is true at $t$ just if $s$ does obtain at some time later than $t$.

2) For any state of affairs $s$ and any time $t$, if $s$ obtains at $t$ then for any time $t^{\prime}$ that is not earlier than $t$ it is necessary at $t^{\prime}$ that $s$ obtain at $t$.

21 Another difference is that thesis (i) seems prima facie to be ranging over events or states of affairs and thesis (iii) rather to be ranging over future-tensed statements, as the latter but not the former speaks of truth. However, Cicero is systematically flexible with regard to what he calls true or false; this difference should be ignored. 
The second of these theses occurs more or less explicitly in T2.a. ${ }^{22}$ The first, however, is presented as two distinct principles in the passage. The relevant part is the following:

Accordingly, if one were to say "Scipio will die at night in his bedroom, overcome by force", one would speak truly, for one would be claiming that that which was going to happen would happen; and indeed, it is a necessary inference from something having happened that it was going to happen.

The claim that "Scipio will die at night in his bedroom, overcome by force" would have been a true statement before Scipio's death is justified by appeal to a general principle (i) according to which any statement to the effect that some state of affairs will obtain is true just when it is in fact the case that that state of affairs is going to obtain. The further claim that "Scipio will die at night in his bedroom, overcome by force" is an instantiation of principle (i) is justified by appeal to principle (ii), namely that if some state of affairs obtains at some time $t$, then it was the case at every time earlier than $t$ that the state of affairs was going to obtain. As Scipio did die at night in his bedroom, overcome by force, it follows from principle (ii) that it was the case at every earlier time that he was going to do so; hence, by principle (i), "Scipio will die at night in his bedroom, overcome by force” was true at every such time. I combine (i) and (ii) into principle 1 above for the sake of simplicity.

Principle 1 is not controversial; it is a natural account of the truth-conditions of future-tensed utterances. Indeed, if one wanted to reject it, one would most probably have to deny bivalence. For to deny principle 1 as it applies, for example, to "Scipio will die at night in his bedroom, overcome by force" would be to assert that at some time $t$ before Scipio's death, the utterance was not true. In making this claim, one has two options: one can assert either that it was false at $t$, or that it was neither true nor false at $t$. The former seems obviously untenable, ${ }^{23}$ but choosing the latter involves denying bivalence.

22 Paragraph 2: “[...] nor can things which will come about be changed from truths to falsehoods any more than things which have happened. But whereas the immutability is evident in the case of that which has happened [...]".

23 However, Plutarch seems to attribute to the Epicureans the view that all future contingents are false (cf. De Pyth. Orac. 399A). But this report cannot be reconciled with the accounts given by Cicero; it should be regarded either as a careless attempt to report the Epicurean view that no future contingents are true, or as a more radical position adopted by a different group of Epicureans. See Warren 2006, 381, and Ferrari 2000, 161. 
Principle 2 is also plausible. The thought behind it is simple: once something has happened, it cannot un-happen. One could reasonably think that before some hypothetical future event happens, measures could be taken either to bring it about or to prevent it: before the sea battle has begun, the admiral may try to avoid it. But it is less plausible that when the sea-battle has occurred, any measures could even in principle be taken to prevent it from having happened; it has become a fixed and unchangeable feature of the world that the sea-battle took place. ${ }^{24}$

There is one doubt about the formulation of the principle: what about the present? Should the principle read, as above, "[...] for any time $t^{\prime}$ that is not earlier than $t$ "; or should it rather read "[...] for any time $t$ ' that is later than $t$ "? The same motivations for considering the past to be immutable suggest that the present is immutable as well. For if a sea battle is currently in progress, one can hardly prevent the sea battle from being currently in progress: the best one could do would be to ensure that the sea battle stops at the closest possible future moment.

The argument is intended to show that the immutability of past and present applies equally to the future. In T2.a, three classes are introduced. Two contain obviously immutable items: they are true statements about the past, on the one hand, and certain true statements about the future, on the other. The example given of the latter is "Scipio will die": the statement is obviously immutably true as every man must necessarily die. The third class, by contrast, contains true statements about the future that are not obviously immutable. These are the future contingents; the example given is "Scipio will die at night in his bedroom, overcome by force”. Although it was necessary for Scipio to die, one would like to think that him dying in that precise way was rather something contingent - he might as well have died during the day by falling off a cliff, or at dawn of a heart attack. The claim put forward here, however, is that the items of the third class are in fact just as immutable - necessary - as those of the first two.

Cicero does not give the details of the argument, but it is straightforward to use the two principles to derive something like a fatalistic result.

\begin{abstract}
A Fatalistic Argument Concerning Scipio's Death
Assume that Scipio dies at night in his bedroom, overcome by force, at time t. Pick an arbitrary time $t^{\prime}$ earlier than $t$ : is it necessary at $t^{\prime}$ that Scipio should die at night in his bedroom, overcome by force?

Consider $\mathrm{u}$, an utterance of "Scipio will die at night in his bedroom, overcome by force"; assess $\mathrm{u}$ at $\mathrm{t}^{\prime \prime}$, where $\mathrm{t}^{\prime \prime}$ is earlier than $\mathrm{t}^{\prime}$. By principle $1, \mathrm{u}$ is true at $\mathrm{t}^{\prime \prime}$ : for what it claims will happen is in fact going to happen (Scipio does indeed die in that manner at some later time,
\end{abstract}

24 Cleanthes denied this principle, perhaps in response to Diodorus' Master Argument (cf. Fat. VII.14), but he seems to have been unusual in this. 
namely $\mathrm{t}$ ). But $\mathrm{t}^{\prime \prime}$ is earlier than $\mathrm{t}^{\prime}$ : hence, by principle 2 , it is necessary at $\mathrm{t}^{\prime}$ that $\mathrm{u}$ be true at $t^{\prime \prime}$. Could one at $t^{\prime}$, therefore, prevent Scipio from dying in that particular way? No: for $u$ can only be true at $\mathrm{t}^{\prime \prime}$ if Scipio does die at night in his bedroom, overcome by force, at some time later than $t^{\prime \prime}$. So if at $t^{\prime}$ one were able to ensure that there is no time at which Scipio dies in that manner, one would (by principle 1) make u not true at $t^{\prime \prime}$. But one cannot do the latter: it is necessary at $\mathrm{t}^{\prime}$ that $\mathrm{u}$ be true at $\mathrm{t}^{\prime \prime}$. Hence, one cannot do the former: it is necessary at $t^{\prime}$ that Scipio should die at night in his bedroom, overcome by force, at some time later than $\mathrm{t}^{\prime \prime}$.

The time t' was arbitrarily chosen, so the result can be generalised: at all times earlier than $\mathrm{t}$, the time of Scipio's death, it is necessary that Scipio should die at night in his bedroom, overcome by force, at some later time.

The move characteristic of this argument is to pass from it now being necessary that a future-tensed utterance was true in the past to it now being necessary that whatever the utterance claimed would happen should happen. The conclusion is not yet that fatalism applies to Scipio's death: for fatalism is the view that for anything that is the case at any time, it is necessary at every time earlier than $t$ that it should be the case at $t$; and all that has been obtained is that it is necessary at every time earlier than the time of Scipio's death that he should die at night in his bedroom, overcome by force, at some later time or other. But this line of this argument is promising; it seems in principle straightforward to adapt it so as to yield fatalism.

First, however, a more urgent question must be addressed. Here is an argument that leads towards fatalism and at least implicitly involves bivalence, in that if one rejected principle 1 one would probably also reject bivalence. But is this relevant to the Epicurean position? Part (b) of T2 suggests that indeed it is.

T2.b (Fat. IX.18-19): nec, cum haec ita sint, est causa, cur Epicurus fatum extimescat et ab atomis petat praesidium easque de via deducat et uno tempore suscipiat res duas inenodabiles, unam, ut sine causa fiat aliquid, ex quo existet, ut de nihilo quippiam fiat, quod nec ipsi nec cuiquam physico placet, alteram, ut, cum duo individua per inanitatem ferantur, alterum e regione moveatur, alterum declinet.

licet enim Epicuro concedenti omne enuntiatum aut verum aut falsum esse non vereri, ne omnia fato fieri sit necesse; non enim aeternis causis naturae necessitate manantibus verum est id, quod ita enuntiatur: "descendit in Academiam Carneades", nec tamen sine causis, sed interest inter causas fortuito antegressas et inter causas cohibentis in se efficientiam naturalem. ita et semper verum fuit "morietur Epicurus, cum duo et septuaginta annos vixerit, archonte Pytharato", neque tamen erant causae fatales, cur ita accideret, sed, quod ita cecidit, serie certa causaram casurum, sicut cecidit, fuit.

Nor, just because these things are so, is there a reason why Epicurus should be terrified of fate and seek help from the atoms and lead them from their path, and why he should at once accept two inexplicable things, the one that something should come about without cause (from which it will follow that something comes about from nothing, which neither he himself nor any physicist accepts), the other that when two atoms are born through empty space, one should move in a straight line and the other swerve. 


\begin{abstract}
For it is possible for Epicurus to concede that every statement is either true or false without fearing that it will be necessary for everything to happen by fate. For it is not through the eternal stream of causes that belong to natural necessity that the statement "Carneades went down to the Academy" is true; neither, however, is it without cause, but there is a difference between accidentally precedent causes and causes which contain in themselves a natural efficiency. Thus it is the case both that "Epicurus will die when he has lived for seventy-two years, during Pytharatus' archonship” was always true, and that there were nevertheless no fating causes as to why it should happen in this way - but, because it did fall out in this way, it was going to befall just as it fell out, by a fixed series of causes.
\end{abstract}

Cicero denies that Epicurus should be motivated by the argument presented in T2.a to assert the two parts of his defence against fate, namely the atomic swerve (described in the first paragraph) and the denial of bivalence (described in the second). Regardless of the details of these criticisms, Cicero's claim that Epicurus should not be motivated by the argument of part (a) in forming his position is only sensible if Epicureans did in fact form their position at least partly in response to it.

In fact, the argument of T2.a fits well with the sketch given in T1. Neither fate nor causation appears in it; it involves a progression from being true ("from eternity" beforehand) to being necessary; and the conception of necessity used in the sketch could well be that of immutability, as here. Indeed, "fixed" is the kind of word one would naturally use to explain the immutability in question: intuitively, what it is that makes things immutable after they have happened is that they have become fixed in the world, established and settled features of it.

Finally, T2.c provides a further indication that one should take the argument of T2.a to underlie the argument that is sketched at the beginning of T1. Here, Cicero makes in general terms the claim that he argued for in T2.b, namely that there is no connection between fate and the argument of T2.a:

T2.c (Fat. IX.20): nec ii, qui dicunt inmutabilia esse, quae futura sint, nec posse verum futurum convertere in falsum, fati necessitatem confirmant, sed verborum vim interpretantur. at qui introducunt causarum seriem sempiternam, ii mentem hominis voluntate libera spoliatam necessitate fati devinciunt.

And those who say that what will happen is immutable, and that a future truth cannot be changed into a falsehood, do not assert the necessity of fate but explain the meaning of words. But as for those who introduce the eternal series of causes, they rob the human mind of free will and bind it with the necessity of fate.

He makes a clear distinction between two groups of people who put forward two separate arguments. His distinction corresponds exactly to that between the two types of argument that seem to be referred to together in T1: in the first sentence of T2.c, he refers to a view according to which "future truths" - i.e. statements about the future which are true - are immutably so; and in its second sentence, he refers to a view according to which there is an eternal chain of causation. He asserts that 
of the two views, only the second entails fate. The first, he claims, merely involves explaining "the meaning of words"; it is unclear what exactly he has in mind when using this phrase, but perhaps he is pointing out that the two arguments seem to operate in different domains. The second involves a thoroughly workedout and controversial doctrine about the nature of causation, whereas the first involves a few apparently anodyne metaphysical and logical assumptions. ${ }^{25}$

There are good grounds, then, to accept this identification. This being so, the details of the argument-sketch in T1 can be supplied on the basis of the argument of T2.a. One alteration should be made, however. While principle 2 remains the same, principle 1 is replaced by principle $1^{\star}$, which is given explicitly at the beginning of the sketch:

$\left.1^{\star}\right)$ For any time $t$ and any utterance $u$, either $u$ is true at $t$ or $\neg u$ is true at $t .^{26}$

2) For any state of affairs $s$ and any time $t$, if $s$ obtains at $t$ then, for any time $t^{\prime}$ that is not earlier than $t$, it is necessary at $t^{\prime}$ that $s$ obtain at $t$.

Before embarking on the general version of the argument, a special type of futuretensed utterance must be found which can be used to pick out particular states of affairs obtaining at particular times. Open-ended utterances such as "Carneades will walk down to the Academy" will not do: as there could be any number of occasions on which Carneades walks down to the Academy, it now being necessary that "Carneades will walk down to the Academy" be true at time $t$ is not sufficient to establish that it is now necessary that Carneades walk down to the Academy at any particular later time, but only that it is now necessary that Carneades walk down to the Academy at some time later than $t .^{27}$ Utterances which include explicit dates and times would serve well to solve this difficulty, but seem mostly to have been foreign to the debate. ${ }^{28}$ Fortunately, a suitable formulation is

25 It is curious that the arguments put forward by the first group of people seem not to worry Cicero - indeed, he appears even to endorse them, here and at De Fat. XII.28. Sedley suggests that he takes this thesis about the necessity of the future to concern only the truth values of futuretensed statements, and therefore to be an "innocuous" view in the realm of tense logic (Sedley 2005, 247-251). However, as Sedley himself observes, the arguments and claims put forward in these passages clearly concern not just certain statements being immutably true, but also things coming about necessarily; the latter seems hardly innocuous. See also Maso 2014, 128.

26 "[...] one or the other [sc. of a pair of contradictories] is true from eternity [...]".

27 The same applies to "Scipio will die at night in his bedroom, overcome by force", the example used in T2.a.

28 "Epicurus will die when he has lived for seventy-two years, during Pytharatus' archonship", in T2.b, looks like it is intended to be such a type of utterance; but it is the only example to be found. 
found in De Natura Deorum and Lucullus (T3 and T4 in section 4), where Cicero uses as examples "Epicurus will be alive tomorrow" and "Hermarchus will be alive tomorrow" and their contradictories. It is clearly not a coincidence that Cicero uses these examples. Utterances of this kind use indexical expressions to specify the time that is a precise interval from the time at which they have a truth value: the only way "Epicurus will be alive in 24 hours' time" can be true at some time $t$ is if Epicurus is alive at the time precisely 24 hours later than $t$. So it now being necessary that "Epicurus will be alive in 24 hours' time" be true at time $t$ suffices to establish that it is now necessary that Epicurus should be alive at $t^{\prime}$, where $t^{\prime}$ is the time exactly 24 hours later than $t$.

It now becomes straightforward to give the general version of the argument, in which the utterances to be used fit the schemata, "In $v$, $\xi$ will be $\Phi$ " and "It is not the case that in $v$, $\xi$ will be $\Phi$ ", where " $v$ " should be replaced by a specification of a time interval, “ $\xi$ ” by a singular term, and “ $\Phi$ ” by a general term.

\section{The General Argument for Fatalism}

Take an arbitrary state of affairs $\mathrm{s}$, such that s consists of some individual $\mathrm{x}$ having some property F. Assume that s obtains at some time t. Pick an arbitrary time $t^{\prime}$ that is earlier than $\mathrm{t}$ : is it necessary at $\mathrm{t}^{\prime}$ that $\mathrm{s}$ obtain at $\mathrm{t}$ ?

Take a time $t^{\prime \prime}$, such that $t^{\prime \prime}$ is earlier than $t^{\prime}$, and earlier than $t$ by time interval $n$. Let $u$ and $\neg \mathrm{u}$ be utterances such that $\mathrm{u}$ is an instance of "In $v$, $\xi$ will be $\Phi$ ” and $\neg \mathrm{u}$ an instance of "It is not the case that in $v$, $\xi$ will be $\Phi$ ", with the appropriate substitutions of a specification of $n$ for " $v$ ", a singular term referring to $\mathrm{x}$ for " $\xi$ ", and a general term denoting $\mathrm{F}$ for " $\Phi$ ". What are the truth-values of $\mathrm{u}$ and $\neg \mathrm{u}$ at $\mathrm{t}^{\prime \prime}$ ? According to principle $1^{\star}$, either $\mathrm{u}$ is true at $\mathrm{t}^{\prime \prime}$ or $\neg \mathrm{u}$ is true at $\mathrm{t}^{\prime \prime}$. $\neg \mathrm{u}$ can hardly be true at $\mathrm{t}^{\prime \prime}$, as $\mathrm{x}$ does have $\mathrm{F}$ at the time that is $\mathrm{n}$ later than $\mathrm{t}^{\prime \prime}$, namely $\mathrm{t}$. So $\mathrm{u}$ is true at $\mathrm{t}^{\prime \prime}$. Hence, from principle 2, it is necessary at $\mathrm{t}^{\prime}$ that $\mathrm{u}$ be true at $\mathrm{t}^{\prime \prime}$ (as $t^{\prime}$ is later than $t^{\prime \prime}$ ). But the only way in which u could be true at $t^{\prime \prime}$ is if s does obtain at the time that is $\mathrm{n}$ later than $\mathrm{t}^{\prime \prime}$, namely $\mathrm{t}$. Hence, it is necessary at $\mathrm{t}^{\prime}$ that $\mathrm{s}$ obtain at $\mathrm{t}$.

As $t^{\prime}$ was arbitrarily chosen, the result can be generalised: at every time earlier than $t$, it is necessary that s obtain at $t$. As $t$ and $s$ were also arbitrarily chosen, the result can be further generalised: for any state of affairs that consists of some individual having some property, and any time at which that state of affairs obtains, it is necessary at every earlier time that the state of affairs obtain at that later time. This is fatalism. ${ }^{29}$

29 One might wonder whether the argument should be further generalised so as to cover more complex states of affairs: not only those that consist of an individual having a property, and correspond to simple predicative utterances, but also those that correspond to complex utterances, such as disjunctions, universal quantifications, and so forth. But Epicurus seems suspicious of complex utterances and would presumably be similarly suspicious of complex states of affairs. Furthermore, it is already sufficiently problematic to have this more limited result. 


\section{Laws of the Excluded Middle}

Epicurus seems to think that this argument is valid - in particular, he seems to accept the passage from truth to necessity that is licensed by principle 2 . But he rejects fatalism, the argument's conclusion; hence, he must reject principle $1^{\star}$, its starting-point. However, Cicero offers the argument as explanation of why Epicurus is unwilling to accept bivalence, and principle $1^{\star}$ is not bivalence, but rather a version of the law of the excluded middle. The questions now at hand, therefore, are that of how this argument could serve as an explanation of why Epicurus rejects bivalence, whether Epicurus distinguishes bivalence from the excluded middle, and what his attitude is to the latter.

I speak of principle $1^{\star}$ as being "a version" of the law of the excluded middle because the law can be formulated in more than one way. Two are especially relevant; I call them the semantic and the syntactic laws of the excluded middle respectively. ${ }^{30}$

\section{Semantic LEM:}

For any time $t$ and any utterance $u$, either $u$ is true at $t$ or $\neg u$ is true at $t$.

Syntactic LEM:

Any utterance that is an instance of the schema " $\sigma$ or it is not the case that $\sigma$ ", where " $\sigma$ " is to be replaced by a well-formed declarative sentence, is true at all times.

There are important differences between these two versions. Given bivalence, the only way to reject the semantic law of the excluded middle is to accept that for some time $t$, some utterance $u$, and its contradictory, $\neg u$, both $u$ and $\neg u$ are false at $t$. But this would be hard to swallow. ${ }^{31}$ Bivalence, together with the assumption that there can be no pairs of contradictories that have the same truth-value at the same time, entails the semantic law. But whether or not bivalence entails the syntactic law depends on one's account of the truth conditions of disjunctions.

Clearly, principle $1^{\star}$ is identical to the semantic law of the excluded middle. It is already evident, therefore, how the argument-sketch of T1 could serve as explanation for the rejection of bivalence: if Epicurus wishes to reject principle $1^{\star}$ in order to avoid the argument's conclusion, he must also reject at least one of the principles that entail it. Presumably, he found bivalence the easier of the two to reject.

30 In doing so, I am influenced by Bobzien 1998, 77.

31 However, note again that Plutarch seems to attribute this view to some Epicureans (De Pyth. Orac. 399A). 
But this is not the end of the story: different formulations of the law turn up in different passages. I begin with De Natura Deorum.

T3 (N.D. I.XXv): idem facit contra dialecticos; a quibus cum traditum sit in omnibus diiunctionibus in quibus "aut etiam aut non" poneretur alterum utrum esse verum, pertimuit ne si concessum esset huius modi aliquid "aut vivet cras aut non vivet Epicurus", alterutrum fieret necessarium: totum hoc "aut etiam aut non" negavit esse necessarium; quo quid dici potuit obtusius?

He [i.e. Epicurus] does the same [i.e. tries to support a position by using a defence that leaves him worse off than he began] against the logicians. While their position is that in all disjunctions in which "Either yes or no" is posited one or the other is true, he was afraid that if something of this type - e.g. "Epicurus either will or will not be alive tomorrow" - were granted, one or other [of its disjuncts] would be necessary: he denied that this whole "Either yes or no" class of statements is necessary. What claim could be more stupid than this?

T3 seems to report the same argument sketched in T1, but in an even more cursory fashion. It too begins by using the semantic law of the excluded middle to assert that one of every pair of contradictories is true, before using the progression from truth to necessity to obtain the undesirable result that one of every pair of contradictories is necessary - although here no explanation whatever is given of the passage from truth to necessity. As before, Epicurus must reject the argument's starting-point, namely the semantic law of the excluded middle.

One curious feature of this passage, however, is the way in which the semantic law is expressed. A shorthand is established for referring to utterances which fit the schema " $\sigma$ or it is not the case that $\sigma$ " - they are "'Either yes or no' statements" - and pairs of contradictories are obtained by speaking of the disjuncts of these utterances. This is curious because the schema is more obviously useful for expressing the syntactic law. In fact, the semantic law could well be taken to be expressed here as the conjunction of the following two principles:

i) Every "Either yes or no" statement is always true.

ii) A disjunction is true when and only when at least one of its disjuncts is true.

Together, they entail the semantic law of the excluded middle; the first of them is, of course, just the syntactic law. Since Epicurus denies what is entailed by their conjunction, he must reject at least one of them. From the conclusion of T3, it looks like he rejects the first. ${ }^{32}$ But one should note that he could just as well have denied the second instead.

32 According to the interpretation I am proposing, one should - strictly speaking - expect to find not "[...] he denied that this whole 'Either yes or no' class of statements is necessary" at the end of the passage, but rather “[...] he denied that this whole 'Either yes or no' class of statements 


\section{A passage from Lucullus contains a similar account.}

T4 (Luc. xxx.97): etenim cum ab Epicuro, qui totam dialecticam et contemnit et inridet, non inpetrent ut verum esse concedat quod ita effabimur "aut vivet cras Hermachus aut non vivet", cum dialectici sic statuant, omne quod ita disiunctum sit quasi "aut etiam aut non" non modo verum esse sed etiam necessarium, vide quam sit cautus is quem isti tardum putant: "si enim" inquit "alterutrum concessero necessarium esse, necesse erit cras Hermachum aut vivere aut non vivere; nulla autem est in natura rerum talis necessitas."

And indeed, although the logicians do not succeed in making Epicurus, who both despises and mocks the whole of logic, concede that what we say thus - "Either Hermarchus will be alive tomorrow or he will not" - is true, when they declare that every disjunction of this "Either yes or no" kind is not just true but also necessary, see how cunning is that man whom they think slow: "For if," he says, "I concede that one or the other is necessary, it will be necessary either for Hermarchus to be alive tomorrow or for him not to be alive; but there is no such necessity in the nature of things."

T4 is hard to make sense of. The most problematic part is the report of Epicurus' reasoning:

"For if," he says, "I concede that one or the other is necessary, it will be necessary either for Hermarchus to be alive tomorrow or for him not to be alive."

To reconcile this reasoning with the argument presented in T1 and implicit in T3, one would expect either to find some phrase that could refer to the disjunction as a whole in place of "one or the other", or to find "true" instead of the first occurrence of "necessary". ${ }^{33}$ As it stands, the passage is most naturally taken to report that Epicurus thinks that a necessity operator governing a disjunction can be distributed amongst its disjuncts, so that from "Necessarily ( $p$ or $q$ )" one can infer "Necessarily $p$ or necessarily $q$." But counter-examples to this fallacy are so

is true". However, this can reasonably be regarded as no more than a careless slip; the description of what Epicurus is unwilling to concede that begins T3 correctly involves truth rather than necessity. A tendency to slip between truth and necessity is understandable when the type of necessity in question is immutability - principle 2 establishes a very close link between truth and necessity/immutability.

33 Indeed, Long/Sedley 1987, 111, describe the passage as "garbled" and suggest the latter. Bobzien suggests that one should take "that one or the other is necessary" to be the conclusion of the argument and "it will be necessary either for Hermarchus to be alive tomorrow or for him not to be alive" to illustrate what is problematic about this general conclusion by instantiating it with a particular example of an obviously contingent pair of contradictories (Bobzien 1998, 79, n. 45). But one would expect the former to be a premise of the argument rather than its conclusion, given that it is introduced as a possible concession ("For if I concede [...]"). 
readily available that it would be alarming for Epicurus to have been convinced by it $^{34}$; it is difficult to see how the passage as a whole can be taken seriously.

However, one important feature of T4 can safely be noted for the purposes of the present discussion, namely that it seems to go even further than T3 in its formulation of the law of the excluded middle. While T3 introduced disjunctions formed from contradictories, T4 begins just with part (i) of the semantic law expressed in T3, i.e. with the syntactic law, and says nothing directly about the truth of the disjuncts of the "Either yes or no" statements. The picture has become complicated: comparing these two passages with T1, it seems most likely that Epicurus did not clearly distinguish the syntactic law from the semantic one, but used them interchangeably and probably rejected them both.

But this pessimism can be dispelled by a passage found later in De Fato, where the Epicurean views on this subject turn out to be subtler:

T5 (Fat. XVI.37): necesse est enim in rebus contrariis duabus (contraria autem hoc loco ea dico, quorum alterum ait quid, alterum negat), ex iis igitur necesse est invito Epicuro alterum verum esse, alterum falsum, ut "sauciabitur Philocteta" omnibus ante saeculis verum fuit, "non sauciabitur" falsum; nisi forte volumus Epicureorum opinionem sequi, qui tales enuntiationes nec veras nec falsas esse dicunt aut, cum id pudet, illud tamen dicunt, quod est inpudentius, veras esse ex contrariis diiunctiones, sed, quae in his enuntiata essent, eorum neutrum esse verum. o admirabilem licentiam et miserabilem inscientiam disserendi!

For it is necessary in two contrary matters (and here I call contraries those of which one affirms something and the other denies it) that one of them - pace Epicurus - be true and the other false, so that "Philoctetes will be wounded" was true for all the centuries beforehand, and "He will not be wounded" false. Unless, by chance, we want to follow the view of the Epicureans, who say that such statements are neither true nor false or, when that shames them, say something yet more shameless, namely that the disjunctions formed from contraries are true, but of the statements which are within these disjunctions neither is true. What remarkable wantonness and pitiable ignorance of argument!

Once again, pairs of contradictories are under discussion. Cicero begins by asserting a principle that seems designed to be a complete characterisation of the relationships between the members of these pairs: in one sentence, it encompasses the semantic law, the law of non-contradiction, and bivalence. Naturally, the Epicureans disagree with this principle, and Cicero presents the two answers they give in disagreement.

The first is brief: they deny the principle of bivalence by saying that "such statements" are neither true nor false. The statements at hand, namely "Philoc-

34 Indeed, the class of disjunctions whose disjuncts are contradictories is an obvious source of counter-examples. 
tetes will be wounded" and "Philoctetes will not be wounded", seem intended to be a typical example of a pair of future contingents; hence, presumably future contingents in general are neither true nor false. The first Epicurean answer, then, is that bivalence does not apply to this class of utterances.

As a reply to Cicero's general principle, this is somewhat lacking. For the Epicureans have said nothing about the principle itself, but only about bivalence, which is merely one of its consequences. It is not surprising, then, that Cicero gives them a second answer ("something yet more shameless") to supplement the first. It comes in two parts:

1) Disjunctions formed from pairs of contradictories are true.

2) Neither of the disjuncts of such a disjunction is true.

Part (1) of the answer is just the syntactic law of the excluded middle, which the Epicureans here affirm to be valid. In part (2), the subject of discourse must carry over from the first answer given by the Epicureans, and therefore be restricted to referring just to those disjuncts which are future contingents: part (2) is a denial that bivalence applies to this class of utterances. ${ }^{35}$

So in their final answer, the Epicureans turn out to endorse the syntactic law of the excluded middle - which they were reported to deny in T3 and T4. One might think that this should immediately land them in the difficulties which they avoided by rejecting the law of the excluded middle in those passages. But not so. For recall that the principle beginning the argument presented in T3 was expressed as the conjunction of the following two principles:

i) Every "Either yes or no" statement is always true.

ii) A disjunction is true when and only when at least one of its disjuncts is true.

The solution in T3 was to reject principle (i) and keep principle (ii). But with their second answer in T5, the Epicureans do the opposite: part (1) of the answer is an affirmation of principle (i), and part (2) amounts to a rejection of principle (ii). Hence, they avoid the difficulties by which they were threatened in T3 and T4, but use a different route to do so.

What is the reason for this discrepancy between the final position reached in $\mathrm{T} 5$ and those reported in $\mathrm{T} 3$ and T4? It seems most likely that it is the result

35 Indeed, if parts (1) and (2) were both allowed unrestricted domain over all possible utterances, they would be incompatible. For consider the following disjunction (where $u$ is some utterance): $(u \vee \neg u) \vee \neg(u \vee \neg u)$. According to (2), $u \vee \neg u$ is not true, as it is a disjunct of a disjunction of a pair of contradictories (namely, the aforementioned disjunction). But according to (1), it is true, as it is itself a disjunction formed from a pair of contradictories. 
of an evolution in the Epicurean theory. ${ }^{36}$ Cicero himself suggests in T5 that the Epicureans held different views at different times, by reporting one answer that is "shameless" and a later answer that is "yet more shameless". Furthermore, the simple fact that the denial of bivalence is not mentioned in the arguments against fatalism that survive in Epicurus' own works (and that the atomic swerve, the other component of his defence, is not mentioned in the Letter to Herodotus) indicates that he most probably held different views at different times on this subject. ${ }^{37}$

I propose, therefore, to take the final view expressed in $\mathrm{T} 5$ to be the definitive version of the Epicurean theory: they reject bivalence and the semantic law of the excluded middle in order to avoid fatalism, but retain the syntactic law of the excluded middle. The position is coherent if they also claim that it is not the case that a disjunction is true only when one or the other of its disjuncts is true. ${ }^{38}$ Doubts remain, however: no justification has been given of this prima facie unlikely claim about the truth conditions of disjunctions. Of course, there are many possible accounts that would have the correct results for the Epicureans. ${ }^{39}$ Jonathan Barnes, for instance, has suggested that the Epicureans hold that a disjunction is true just when not all its disjuncts are false. ${ }^{40}$ This account has the correct result for future contingents: as neither "Philoctetes will be wounded" nor "Philoctetes will not be wounded" is false (or true) before the wounding in question, "Philoctetes will be wounded or Philoctetes will not be wounded" comes out as true. But the account has further results that are profoundly counter-intuitive, since it verifies every disjunction whose disjuncts are future contingents, so that also "Philoctetes will be wounded or Philoctetes will be wounded" and "Philoctetes will not be wounded or Philoctetes will not be wounded" turn out

36 Less charitable answers would be that the Epicureans are incoherent, or that Cicero has misrepresented them.

37 As the Epicurean school seems to have been doctrinally conservative, it is unlikely that these rather substantial theses were all innovations by later Epicurean philosophers. However, Ferrari 2000,161 , suggests with some plausibility that the basic denial of bivalence may have been due to Epicurus and the more complex views on the truth-values of disjunctions and their disjuncts to later Epicureans.

38 It is worth remarking that this is precisely the position which some commentators have attributed to Aristotle on the basis of De Interpretatione 9. See, for example, Crivelli 2004, 198-225. This may not be a coincidence: Epicurus seems to have read at least some Aristotle (see Sedley 1977, $236 \mathrm{f}$., and, for some cautionary remarks, Sandbach 1985, 4f.)

39 The truth-conditions of disjunctions were up for debate in the Hellenistic period - there was, for example, a long-standing Stoic debate over whether they are truth-functional (cf. Mates 1953, 51-54).

40 See Barnes 2007, 90. 
to be true. This interpretation saddles the Epicureans with a view which seems unmotivated; it does not look like a plausible account of disjunctions.

My task in the next two sections, therefore, is to find an account which has the correct results with respect to the truth-values of future contingents and of disjunctions, can reasonably be attributed to the Epicureans, and is not without a certain degree of plausibility.

\section{The Chrysippean Argument for Fate}

To this end, I turn to the Chrysippean argument from bivalence to fate and to its Epicurean response. It is true that Cicero's presentation of the Epicurean views as a response to this Chrysippean argument is probably anachronistic; furthermore, there is little independent reason to think that Epicurus' views on bivalence and fatalism were connected to his views on causation and fate. ${ }^{41}$ Nonetheless, it is only fair to think that Cicero takes care to attribute positions to the Epicureans that they did in fact hold, even if he presents them in a misleading way; and it turns out, as I shall argue, that the positions to which the Epicureans seem to commit themselves when responding to the argument for fate naturally suggest a model of truth at times that yields the correct results for their response to the argument for fatalism.

Cicero gives the Chrysippean argument in full at the beginning of chapter $\mathrm{x}$ (immediately following T2, and slightly before T1):

T6 (Fat. x.20f.): sed haec hactenus; alia videamus. concludit enim Chrysippus hoc modo: "si est motus sine causa, non omnis enuntiatio, quod ' $\alpha$ '́í $\omega \mu \alpha$ ' dialectici appellant, aut vera aut falsa erit; causas enim efficientis quod non habebit, id nec verum nec falsum erit; omnis autem enuntiatio aut vera aut falsa est; motus ergo sine causa nullus est. quod si ita est, omnia, quae fiunt, causis fiunt antegressis; id si ita est, fato omnia fiunt; efficitur igitur fato fieri, quaecumque fiant."

But enough of this; let us consider other subjects. For Chrysippus drew his conclusion in the following manner: "If there is uncaused motion, it will not be the case that every proposition - what the logicians call an ' $\alpha \xi^{\prime}(\omega \mu \alpha$ ' - is either true or false: for that which will turn out not to have efficient causes will be neither true nor false. However, it is the case that every proposition is either true or false: therefore, there is no uncaused motion. And if this is so, then everything that comes about does so according to antecedent causes; and if that is so, then everything comes about by fate. It follows, therefore, that whatever comes about does so by fate."

41 Cf. Bobzien 1998, $83 \mathrm{f}$. 
The argument can be regimented as follows:

1) If there is uncaused motion, it is not the case that bivalence holds.

2) But bivalence holds.

3) Hence (from 1 and 2), it is not the case that there is uncaused motion.

4) If it is not the case that there is uncaused motion, everything that happens is caused.

5) Hence (from 3 and 4), everything that happens is caused.

6) If everything that happens is caused, everything that comes about does so by fate.

7) Hence (from 5 and 6), everything that comes about does so by fate.

I have given steps 4 to 7 in full to make it clear that the argument is valid according to Chrysippean propositional logic. ${ }^{42}$ They are uncontroversial: premise 4 is justified by “ $\neg x P x$ ” implying “ $\forall x P x$ ” for any $P$; premise 6 is justified on the basis of a definitional equivalence, as for everything to come about by fate just is for everything to come about according to antecedent efficient causes; and steps 5 and 7 depend on Chrysippus' first indemonstrable (i.e. modus ponens). ${ }^{43}$ They are so uncontroversial, in fact, that once one has derived step 3, by Chrysippus' second indemonstrable (i.e. modus tollens), one can reasonably consider oneself already to have the result that everything comes about by fate.

It is not surprising that Epicurus' reply comes in two parts. By denying bivalence, he denies premise 2 and renders the argument unsound; by introducing the atomic swerve, a prime example of uncaused motion, he denies step 3 and can use an argument parallel to that which goes from 3 to 7 to go from the negation of 3 to the negation of 7 . If one grants that there is uncaused motion, one must deny that everything that comes about does so by fate. (Of course, it is unlikely that this is the only reason the Epicureans have to introduce the atomic swerve; indeed, it is unlikely that they introduced it in direct response to this argument at all. But it is plausible that some Epicurean could have appealed to the atomic swerve in the course of a defence against the Chrysippean argument for fate, or that Epicurus himself could have appealed to it in response to similar arguments by earlier philosophers.)

Chrysippus' argument and Epicurus' reply to it are clear in outline. But what is the motivation for premise 1, which seems prima facie mysterious? Epicurus is free to choose between denying premise 1 and denying premise 2; why should

42 Compare Bobzien 1998, 61f., and Schallenberg 2008, 168-172.

43 Here, one must also appeal to strong double negation. 
he not do the former? A hint as to the relation between bivalence and uncaused motion is given in T6 itself, at the end of the second sentence: "for that which will turn out not to have efficient causes [i.e. if bivalence is rejected] will be neither true nor false”. An expansion of this hint occurs later in De Fato.

T7 (Fat. XI.26-XII.27): quod cum ita sit, quid est, cur non omnis pronuntiatio aut vera aut falsa sit, nisi concesserimus fato fieri, quaecumque fiant? quia futura vera, inquit, non possunt esse ea, quae causas, cur futura sint, non habent; habeant igitur causas necesse est ea, quae vera sunt; ita, cum evenerint, fato evenerint. [...] an aliter haec enuntiatio vera esse non potest: “capiet Numantiam Scipio", nisi ex aeternitate causa causam serens hoc erit effectura?

This being so, why is it that not every proposition is either true or false, unless we concede that whatever happens does so by fate? Because, he says, future things cannot be true without having causes as to why they will come about; therefore those which are true must necessarily have causes; thus when they have occurred, they will have occurred by fate. [...] Could this statement - "Scipio will take Numantia" - be true otherwise than if cause linked to cause from eternity is not going to bring it about?

A curious feature of $\mathrm{T} 7$ is that it is not obvious from the context whose views are in question - it is not obvious to whom Cicero is referring when he writes "he says" in the second sentence. Chrysippus and Epicurus are both good candidates, as both have been mentioned shortly beforehand and both more or less agree about the principle endorsed in the passage. Perhaps, however, Chrysippus is slightly more promising, as the tone of the question with which Cicero opens the passage suggests that it is directed at someone who wants his audience to concede that everything happens by fate, rather than at someone who wants his audience to concede that bivalence does not hold. ${ }^{44}$

This difficulty aside, the explanation given in T7 is reasonably clear: Chrysippus (or Epicurus) claims that a necessary condition for a "future thing" - presumably, a future-tensed proposition - to be true is that there be causes of its coming about. More precisely, it looks like he is claiming that for any time $t$, if the proposition that Scipio will take Numantia (for example) is true at $t$ then there must be a collection of states of affairs that obtain at $t$ which are, by obtaining at $t$, causes of Scipio taking Numantia at some later time $t^{\prime}$, either by causing it

\footnotetext{
44 All things being equal, the rather explicit talk of fate and causation would seem more characteristic of a Stoic than of an Epicurean; this consideration is of no help here, however, as Cicero frequently attributes detailed views on causation to the Epicureans in these passages. The traditional view is to opt for Chrysippus - all of Yon 1944, Bayer 1963, Sharples 1991, Antonini 1994, Bobzien 1998 and Schallenberg 2008 do so. Sedley 2005, O’Keefe 2005, Atherton 2007 and Maso 2014, however, opt for Epicurus instead.
} 
directly or by being predecessors in the causal chain that will bring it about. ${ }^{45}$ Most probably, Chrysippus would also endorse the other direction of implication, which is comparatively uncontroversial: if there is at $t$ such a collection of states of affairs which, by obtaining at $t$, are causes of Scipio taking Numantia at some later time $t^{\prime}$, then the proposition that Scipio will take Numantia is true at $t$. In general, then, he seems to accept the following principle (which I formulate for propositions which fit the useful schema "In $v$, $\xi$ will be $\Phi$ ”):

PFT (“Principle of Future Truth"):

For any time $t$ and any proposition $p$ to the effect that some individual $x$ will have some property $F$ in time interval $n, p$ is true at $t$ if and only if there is some state of affairs or collection of states of affairs that obtains at $t$ and which, by obtaining at $t$, is a cause of $x$ having $F$ at $t^{\prime}$, where $t^{\prime}$ is $n$ later than $t$, either by causing it directly or by being a predecessor in the causal chain which brings it about.

This principle provides adequate support, if accepted, for premise 1 of the argument for fate, namely "If there is uncaused motion, it is not the case that bivalence holds". For assume that there is an instance of uncaused motion - assume that atom $a$ swerves at time $t$ without cause. Now consider the status of the proposition "Atom $a$ will swerve in 24 hours' time" at $t^{\prime}$, where $t^{\prime}$ is 24 hours earlier than $t$. This proposition is not false at $t^{\prime}$ : for atom $a$ does swerve 24 hours later, at $t$. But neither can it be true at $t^{\prime}$ : for the event of atom $a$ swerving at $t$ has no cause, and hence, a fortiori, no cause at $t^{\prime}$. Therefore the proposition is neither true nor false - bivalence fails to hold universally.

PFT, then, is what must motivate Chrysippus in proposing premise 1 in the first place, and Epicurus in choosing to reject bivalence rather than that premise. But it is hardly obviously correct as it stands. Indeed, this is precisely the criticism levelled by Carneades and Cicero against the Chrysippean argument and the Epicurean response to it: they deny premise 1 and the principle that underlies it rather than rejecting bivalence. The criticism is made against Chrysippus on several occasions in De Fato, ${ }^{46}$ and is identical to the version already quoted in T2.b, where Cicero makes it against Epicurus:

45 Here, I certainly misrepresent Chrysippus' position in one important respect: Chrysippus does not think that something like (the state of affairs of) Scipio taking Numantia is the kind of thing that could be either a cause or an effect. Rather, on his view it is a body that is a cause when it acts on another body, and an incorporeal predicate that is an effect (cf. Sextus Empiricus M. IX 211; see Bobzien 1998, 18-21, for more details). But this detail does not affect the present discussion in any important respect; I omit it so as to make comparisons with the Epicurean views easier.

46 See in particular Fat. XII.27 f. and xIv.32f. 
For it is not through the eternal stream of causes that belong to natural necessity that the statement "Carneades went down to the Academy" is true [...] Thus it is the case both that "Epicurus will die when he has lived for seventy-two years, during Pytharatus' archonship" was always true, and that there were nevertheless no fating causes as to why it should happen in this way [...].

On the face of it, this seems a reasonable criticism. How might Epicurus and Chrysippus respond? Perhaps they are motivated by puzzlement about what it is for it now to be true that something will happen - for it now to be true that Scipio will take Numantia, for example. Puzzlement about this would not arise if one adopted an atemporal notion of truth, according to which it would straightforwardly be timelessly true that Scipio takes Numantia in 133 BC just as it is timelessly true that $2+2=4$ - the specification of time turns out to be redundant with respect to the ascription of truth. But if one takes a temporal notion of truth seriously, as Chrysippus and Epicurus seem to do, one might reasonably wonder in virtue of what "Scipio will take Numantia" could be true in 135 BC. Scipio taking Numantia is not a feature of the world in $135 \mathrm{BC}$ - it will only become so in $133 \mathrm{BC}-$ so it is hard to see how it could be this that makes "Scipio will take Numantia" true in $135 \mathrm{BC}$, when it is not yet there to do so.

If this is a worry that Epicurus and Chrysippus have, then PFT provides a simple solution to it. According to this principle, a future-tensed proposition is presently true just if there are features of the present state of the world that determine that the event of which it speaks is bound to come about. ${ }^{47}$ In the case of "Scipio will take Numantia", the relevant features are likely to involve the conditions of the Roman and Numantian armies, the expertise of their respective generals, and other such factors. If one takes the relevant features of the state of the world in $135 \mathrm{BC}$, applies the various laws of causal interaction to them, and thereby finds that Scipio is bound to take Numantia, one may conclude that "Scipio will take Numantia" was true in 135 BC - in a sense, it is true in virtue of these features of the world of $135 \mathrm{BC}$. Analogously, if one finds that these features of the world rule out the possibility of Scipio ever taking Numantia, one may conclude that "Scipio will take Numantia" was false in 135 BC. But if such a procedure suffices neither to require nor to rule out Scipio taking Numantia, one might well be tempted to conclude that "Scipio will take Numantia" was neither

47 PFT could loosely be called a truth-maker principle. Compare O’Keefe 2005, 141f. I am broadly in agreement with O'Keefe that this principle or something like it is, for Epicurus, what links fatalism and the logical principles of bivalence and the excluded middle, on the one hand, to questions of causation and the atomic swerve, on the other. See also Bobzien 1998, 65-71, and Schallenberg 2008, 192-6. 
true nor false in 135 BC: there is nothing about the world of 135 BC that makes it a world in which Scipio will take Numantia rather than a world in which he will not, or vice versa. ${ }^{48}$

\section{Branching Time and Future Truth}

If Epicurus were convinced by something like the above, perhaps he would have some reason not to reject premise 1 . One might wonder, however, whether he can endorse PFT as it stands. For it uses the laws of causation as the criteria of whether a given outcome is the determinate result of a particular situation - but with the atomic swerve, Epicurus does away with the eternal chain of causation that determines how everything will turn out. The Chrysippean model of the passage between any earlier time $\alpha$ and later time $\beta$ could be represented by an unbroken horizontal line:

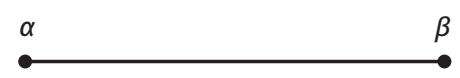

Every aspect of $\beta$ is fully determined by some aspect of $\alpha$; if one takes the rules of causal interaction and applies them to $\alpha$, one cannot fail to end up with $\beta$.

By modifying the Chrysippean picture of the passage of time with the addition of the atomic swerve, however, a different picture results. Given the atomic swerve, any atom travelling on any path may at any moment causelessly change direction. Hence, any time is succeeded by numerous different and incompatible future times, each corresponding to a different way in which the atoms swerve or fail to swerve. Rather than an unbroken horizontal line, then, the Epicurean model of time corresponds to a tree-structure: every time is immediately succeeded by numerous different and mutually incompatible future times, but preceded by a single linear ordering of past times. The idea is that one's past is fixed, but one's future indeterminate; there is more than one possible future that may succeed any given time:

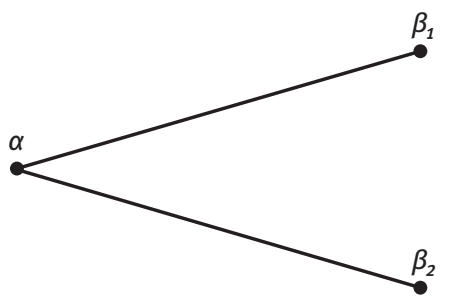

48 See Tooley 1997, 128, for a (very roughly) similar contemporary treatment. 
So, an earlier time $\alpha$ is followed by more than one later time. Those represented here $-\beta_{1}$ and $\beta_{2}-$ must differ from one another in some respect, even if it is only the position of a single atom. In fact, as it seems that any atom may swerve at any time, and as Epicurus holds that there are an infinite number of atoms, every earlier time is immediately succeeded by an infinite number of incompatible possible later times, one for each combination of atomic swerves.

But Epicurus does not do away with causation entirely: the atomic swerve is only a minimal exception to the Chrysippean chain of causation, capable of making only rather small differences of a precisely characterised type. ${ }^{49}$ Consider a situation in which a ball is released in mid-air and allowed to drop to the ground. On the Chrysippean account, a superhuman mind that knew all the relevant details of the state of the world when the ball is released could calculate the spot at which the ball will inevitably hit the ground. On the Epicurean account, such a mind could not do this - there is no such exact spot which the ball is bound to hit. However, it could identify precisely those spots at which the ball might hit the ground, and it can rule out many end results as impossible. For example, it can rule out futures in which the ball flies off to one side or rockets up to the ceiling. These considerations suggest that the appropriate Epicurean version of PFT would be a principle according to which a future-tensed utterance is true at some time $t$ just if its truth is required by all the possible times that succeed $t$ (as it might be required that the ball hit the ground somewhere within a certain area).

49 The precise details of the atomic swerve are somewhat controversial and do not make much difference with regard to my present account, so I will not argue here for one interpretation over another. I will, however, give a rough idea of just one plausible interpretation. The theory of the atomic swerve seems to presuppose that time and space as well as bodies have minimal parts - although Epicurus himself mentions neither the atomic swerve nor that time and space are discrete in his account of physics in the Letter to Herodotus - so I will assume that there are minimal atomic intervals both of time and of space. The simplest case of the atomic swerve, then, is as follows. Take an atom, $a$, which is travelling in a straight line on a course that should, given all the laws of physics except that of the atomic swerve, take it through a series of points, $p_{1}$ to $p_{n}$, each of which is a minimal distance from the point that succeeds it in the sequence. Say that $a$ finds itself at $p_{1}$ at time $t_{1}$. All atoms at all times move at the speed of one minimal unit of space per minimal unit of time; hence, one would expect to find $a$ at $p_{2}$ at the next instant of time, $t_{2}$. But according to the view that atoms swerve, this is not bound to happen: in fact, one may well find $a$ not at $p_{2}$ but rather at $r_{2}$, where $r_{2}$ is to be found one minimal unit of space distant from $p_{2}$ in a direction perpendicular to the direction in which $a$ is travelling at $t_{1}$. However, $a$ will still be travelling in the same direction at $t_{2}$ as it was at $t_{1}$; it has merely been displaced by one minimal unit to a course parallel to its original route. Sedley has usefully likened this to changing lanes when travelling on a motorway (Sedley 1976, 25). See Sedley 1983, 41 f., and Englert 1987, 13-26, for more details. 
Analogously, a future-tensed utterance is false at some time $t$ just if it is ruled out by all the possible times that succeed $t$ (as the ball hitting the ground outside a certain area might be ruled out). Some statements can be neither required nor ruled out: these are neither true nor false. ${ }^{50}$

To put the sketch that I have just given more precisely, the notion of a branch must be introduced. Let a branch of the Epicurean tree of time be a maximal linear ordering of times. Intuitively speaking, if one could expand the diagram given above so as to represent and order all possible times, every unique leftto-right unbroken line would represent a single branch (and the expansion of the single left-to-right line in the diagram of the Chrysippean model corresponds to the branch on which no swerves occur). Many branches travel the same path as each other for a while, including exactly the same sequence of times, before parting ways; having separated, two branches can never rejoin. Two branches part ways just when an atom swerves in one but fails to swerve, or swerves differently, in the other.

Next, I introduce the notion of being correct at a time relative to a branch. An open-ended predicative statement about the future, to the effect that some individual $x$ will have some property $F$, is correct at a time $t$ relative to a branch $b$ just if $x$ does have $F$ at some time $t_{1}$ such that $t_{1}$ is included in $b$ and later than $t$. Similarly, a statement to the effect that some individual $x$ will have some property $F$ in time interval $n$ is correct at a time $t$ relative to a branch $b$ just if $x$ does have $F$ at the time $t_{1}$, where $t_{1}$ is included in $b$ and $n$ later than $t^{51}$

The Epicurean characterisations of future truth and falsehood can now be given. An utterance about the future is true at a time $t$ just if it is correct at $t$ relative to every branch which includes $t$. An utterance about the future is false at a time $t$ just if it is not correct at $t$ relative to any branch which includes $t$. So if an utterance about the future is correct at a time $t$ relative to some but not all branches which include $t$, the utterance is neither true nor false at $t$.

In fact, these principles about future truth and falsehood can safely be extended to principles about truth and falsehood in general, namely:

An utterance is true at a time $t$ just if it is correct at $t$ relative to every branch which includes $t$.

and

50 One should be wary about attributing too detailed a theory of causation to the Epicureans (cf. Atherton 2007, 199), so I adopt this relatively neutral formulation of the truth-making principle. 51 The correctness conditions of present- and past-tensed utterances are just as one would expect. 
An utterance is false at a time $t$ just if it is not correct at $t$ relative to any branch which includes $t$.

The extension of the principles is uncontroversial because the branches which include a time $t$ only differ with respect to the times that succeed $t$ - they are identical with regard to $t$ itself and the times that precede it. Hence, if a presentor past-tense utterance is correct at $t$ relative to any branch which includes $t$, it is correct at $t$ relative to every such branch; if it is not correct at $t$ relative to one such branch, it is not correct at $t$ relative to any such branch.

This unified characterisation of truth and falsehood has exactly the characteristics that were demanded in the Epicurean reply to the argument from bivalence to fatalism. The Epicurean reply was that bivalence and the semantic law of the excluded middle do not hold universally - they do not apply to future contingents - but that the syntactic law of the excluded middle is valid. It should be evident that the characterisation of truth and falsehood I have now attributed to the Epicureans commits them to a form of supervaluationism about truth at times - and it has been well established that such a theory has the desired consequences. ${ }^{52}$ I will therefore give only a brief sketch of the result.

I begin with bivalence. Consider the familiar example of Scipio taking Numantia: take $u$, an utterance of "Scipio will take Numantia", and assess it at some time in $133 \mathrm{BC}$, i.e. when it is still undetermined as to whether Scipio will take Numantia or not; call this time " $t$ ". Is $u$ true at $t$ ? No: for $u$ is not correct at $t$ relative to all branches that include $t$ - it is not correct at $t$ relative to the branches in which Scipio does not take Numantia. Is $u$ false at $t$ ? No: for $u$ is correct at $t$ relative to some branches that include $t$, namely those in which Scipio does take Numantia. Hence, bivalence fails for $u$ at $t$ : it is neither the case that $u$ is true at $t$, nor the case that $u$ is false at $t$.

Next, I turn to the semantic law of the excluded middle. In addition to $u$, consider also $\neg u$, an utterance of "It is not the case that Scipio will take Numantia". It has already been shown that $u$ is not true at $t$. But is $\neg u$ true at $t$ ? No: for $\neg u$ is not correct at $t$ relative to all branches that include $t$; it is not correct at $t$ relative to the branches in which Scipio does take Numantia. Hence, the semantic law of the excluded middle fails for $u$ at $t$ : it is neither the case that $u$ is true at $t$, nor that $\neg u$ is true at $t$.

Finally, I treat the syntactic law of the excluded middle. First, what is it for a disjunction (of the inclusive type) to be correct at a time relative to a branch? The

52 See Thomason 1970. Schallenberg 2008, 217-221, observes that it could save the Epicurean position. 
obvious answer involves appealing to its usual truth conditions: a disjunction is correct at a time relative to a branch just if at least one of its disjuncts is correct at that time, relative to that branch.

Consider, then, $u \vee \neg u$, an utterance of "Scipio will take Numantia or it is not the case that Scipio will take Numantia.” Is $u \vee \neg u$ true at $t$ ? Take an arbitrary branch $b$ that includes $t$. There are precisely two possibilities: either $u$ is correct at $t$ relative to $b$, or $u$ is not correct at $t$ relative to $b$. Suppose, first, that $u$ is correct at $t$ relative to $b$. Then $u \vee \neg u$ is correct at $t$ relative to $b$ (by the correctness conditions of disjunctions). Suppose, second, that $u$ is not correct at $t$ relative to $b$. Then it is not the case that Scipio takes Numantia in $b$; hence, $\neg u$ is correct at $t$ relative to $b$. So $u \vee \neg u$ is correct at $t$ relative to $b$. On either supposition, therefore, $u \vee \neg u$ is correct at $t$ relative to $b$. But $b$ was chosen arbitrarily, so the result can be generalised: $u \vee \neg u$ is correct at $t$ relative to every branch that includes $t$. Hence, $u \vee \neg u$ is true at $t$ : the syntactic law of the excluded middle holds for $u$ at $t$.

It should be clear that there is nothing special about the example of Scipio taking Numantia: in general, bivalence and the semantic law of the excluded middle will not hold for any pair of contradictory future-tensed utterances at any time at which they are contingent, whereas the syntactic law of the excluded middle will hold at all times for all pairs of contradictories. The Epicurean position turns out to be coherent.

\section{Concluding Remarks}

I have argued that the Epicurean defence against fatalism can be taken to be complex but coherent. Three logical principles are at issue, namely the principle of bivalence and the semantic and syntactic laws of the excluded middle. Cicero does not attribute entirely consistent positions to the Epicureans with respect to these three principles, but the most sophisticated version, presented as the most developed Epicurean view on the matter, involves rejecting bivalence and the semantic law but endorsing the syntactic law of the excluded middle.

In order to establish what model of truth at times the Epicureans might use to justify this position, I turned to Cicero's report of the Epicurean reply to the Chrysippean argument for fate. It turns out that some of the principles which the Epicureans seem to endorse in this context are relevant to their views on bivalence and the excluded middle. For the Epicureans seem at least to be reluctant to reject the Chrysippean truth-making principle for future-tensed propositions according to which a proposition claiming that a future event will take place is true at time $t$ just if there is some aspect of the world at $t$ in virtue of which the 
future event cannot fail to take place, given the laws of causation. This principle provides the crucial link between bivalence and the laws of the excluded middle, on the one hand, and the Epicurean account of causation and the atomic swerve, on the other. For when Chrysippus' deterministic view of physical causation is modified by the addition of the atomic swerve and combined with this truth-making principle, a supervaluationist model of truth at times ensues: any time is succeeded by an infinite number of incompatible future times, and an utterance is true at a time just if it is correct at that time relative to every branch that includes it. This model has the correct results: it allows the Epicureans to reject the principle of bivalence and the semantic law of the excluded middle in order to avoid being forced to accept fatalism by the argument from truth to necessity, but nonetheless to mitigate the damage this rejection causes by retaining the syntactic law of the excluded middle. Hence, the Epicurean position turns out to be coherent and well-motivated. Despite their infamous disregard for logic, they are not as careless in their treatment of bivalence and the excluded middle as Cicero seems to think. ${ }^{53}$

Adv. Colot. Adversus Colotem

De Pyth. Orac. De Pythiae oraculis

Fat. De Fato

N.D. De Natura Deorum

M Adversus Mathematicos

Antonini, F. (ed.) 1994. Cicerone. Il fato. Milan.

Arrighetti, G. 1973. Epicuro. Opere: introduzione, testo critico, traduzione e note. Turin.

Atherton, C. 2007. "Reductionism, Rationality and Responsibility: A Discussion of Tim O'Keefe,

Epicurus on Freedom". Archiv für Geschichte der Philosophie 89, 192-230.

Barnes, J. (2007). Truth, etc. Oxford.

Bayer, K. (ed.) 1963. M. Tulli Ciceronis de Fato. Munich.

Bobzien, S. 1993. “Chrysippus' Modal Logic and its Relation to Philo and Diodorus”. In:

Dialektiker und Stoiker. Zur Logik der Stoa und ihrer Vorläufer. Eds. K. Döring/T. Ebert.

Stuttgart, 63-84.

-. 1998. Determinism and Freedom in Stoic Philosophy. Oxford.

Crivelli, P. 2004. Aristotle on Truth. Cambridge.

53 Predecessors of this paper were presented at the Fondation Hardt in Vandoeuvres and to the eidos research group in Geneva; I thank those who attended these occasions for their helpful questions and remarks. I am also grateful to the anonymous referees consulted by this journal for their useful comments. Above all, I would like to thank Paolo Crivelli for his invaluable guidance and advice. Of course, I bear full responsibility for the paper's remaining defects. 
Englert, W. G. 1987. Epicurus on the Swerve and Voluntary Action. American Classical Studies 16. Atlanta, GA.

Ferrari, F. 2000. "La falsità delle asserzioni relative al futuro: un argomento epicureo contro la mantica in Plut. Pyth. Orac. 10". In: Epikureismus in der späten Republik und der Kaiserzeit. Ed. M. Erler. Stuttgart, 149-163.

Isnardi Parente, I. 1990. “Diogeniano, gli epicurei e la túxn”. Aufstieg und Niedergang der römischen Welt 36, 2424-2445.

Laursen, S. 1997. "The later parts of Epicurus, On nature, 25th book”. Cronache Ercolanesi 27, $5-82$.

Long, A. A./D. Sedley 1987. The Hellenistic Philosophers. Vol.1. Cambridge.

Maso, S. 2014. Cicerone: Il fato. Rome.

Mates, B. 1953. Stoic Logic. Berkeley/Los Angeles.

Morel, P.-M. 2013. “Epicuro e la desacralizzazione della necessità". In: Fate, Chance, and Fortune in Ancient Thought. Eds. F. G. Masi/S. Maso. Amsterdam, 159-176.

O'Keefe, T. 2005. Epicurus on Freedom. Cambridge.

Percival, P. 1994. "Absolute Truth”. Proceedings of the Aristotelian Society 94, 189-213.

Sandbach, F. H. 1985. Aristotle and the Stoics. Proceedings of the Cambridge Philological Society, Supplementary Volume no. 10. Cambridge.

Schallenberg, M. 2008. Freiheit und Determinismus. Berlin/New York, N. Y.

Sedley, D. 1976. "Epicurus and the Mathematicians of Cyzicus”. Cronache Ercolanesi 6, 23-54.

-. 1977. "Epicurus and His Professional Rivals". Cahiers de Philologie 1: Études Sur L'Épicurisme Antique. Eds. J. Bollack/A. Laks. Lille, 119-59.

- 1983. “Epicurus' Refutation of Determinism”. In: $\Sigma Y Z H T H \Sigma I \Sigma$. Studi sull' Epicureismo greco e latino offerti a Marcello Gigante. Naples, 11-51.

-. 2005. "Verità futura e causalità nel De fato di Cicerone". In: La Catena delle Cause. Eds.

C. Natali/S. Maso. Amsterdam, 241-254.

Sharples, R. W. (ed.) 1991. Cicero: On Fate (De Fato) \& Boethius: the Consolation of Philosophy (Philosophiae Consolationis). Warminster.

-. 2007. "'Sed haec hactenus: alia videamus', De fato 20". Lexis 25, 53-68.

Thomason, R. H. 1970. “Indeterminist Time and Truth-Value Gaps”. Theoria 36, 264-281.

Tooley, M. 1997. Time, Tense, and Causation. Oxford.

Verde, F. 2013. Elachista: La dottrina dei minimi nell'Epicureismo. Leuven.

Warren, J. 2006. "Epicureans and the Present Past". Phronesis 51.4, 362-387.

Weidemann, H. 2007. “Cicero, De fato 11-18A”. Lexis 25, 35-51.

Yon, A. (ed.) 1944. Cicéron. Traité du destin. Paris. 